Article

\title{
Effects of Graded Levels of Mimosa (Acacia mearnsii) Tannin Purified with Organic Solvents on Gas, Methane, and In Vitro Organic Matter Digestibility of Eragrostis curvula Hay
}

\author{
Shehu Lurwanu Ibrahim (D) and Abubeker Hassen *(D) \\ Department of Animal Science, University of Pretoria, Hatfield, Pretoria 0028, South Africa; \\ abumubarak480@gmail.com \\ * Correspondence: abubeker.hassen@up.ac.za; Tel.: +27-(0)1-2420-3273
}

check for

updates

Citation: Ibrahim, S.L.; Hassen, A. Effects of Graded Levels of Mimosa (Acacia mearnsii) Tannin Purified with Organic Solvents on Gas, Methane, and In Vitro Organic Matter Digestibility of Eragrostis curvula Hay. Animals 2022, 12, 562. https:// doi.org/10.3390/ani12050562

Academic Editor: Massimo Trabalza-Marinucci

Received: 3 November 2021 Accepted: 20 January 2022

Published: 23 February 2022

Publisher's Note: MDPI stays neutral with regard to jurisdictional claims in published maps and institutional affiliations.

Copyright: () 2022 by the authors. Licensee MDPI, Basel, Switzerland. This article is an open access article distributed under the terms and conditions of the Creative Commons Attribution (CC BY) license (https:// creativecommons.org/licenses/by/ $4.0 /)$.
Simple Summary: Enteric methane emission serves as one of the major contributors to global warming, and is responsible for the loss of an appreciable amount of dietary energy. Utilization of Mimosa tannin in reducing methane yield in ruminants is well documented. However, its supplementation in large amounts affects rumen fermentation and digestibility, attributed to the presence of a high number of hydrolysable tannins and other non-tannin substances, which poison rumen microorganisms. Purification might remove the toxic compounds, thereby decreasing the methane without affecting the digestibility of the diet. In this study, mimosa tannin was purified with organic solvents (ethyl acetate and pentanol) using the Soxhlet extraction method, and the influence of different concentrations $(10,20,30$, and $40 \mathrm{~g} / \mathrm{kg} \mathrm{DM})$ of the purified tannins on gas, methane, and in vitro organic matter digestibility of Eragrostis curvula hay were evaluated in comparison with the same levels of unpurified tannin. The addition of lower levels of ethyl acetate and pentanol purified mimosa tannin extracts reduced in vitro gas and methane production without adverse effects on dry matter digestibility.

Abstract: The higher contribution of methane $\left(\mathrm{CH}_{4}\right)$ to global anthropogenic potential is a cause of concern to livestock producers. Mimosa tannin gained recent acceptance as an additive for enteric $\mathrm{CH}_{4}$ mitigation. However, rumen fermentation and digestibility are compromised when large quantities of tannins are supplemented due to the presence of hydrolysable tannin and other non-tannin molecules in mimosa extract, which are toxic to animals. Purification could eliminate the toxins, and thus, reduce the $\mathrm{CH}_{4}$ yield without negative effects on rumen microbial activities and organic matter degradation. The Soxhlet extraction method was used to purify the tannin using organic solvents (ethyl acetate and pentanol). The unpurified, ethyl acetate purified, and pentanol purified tannins at the dosages of 10,20,30, and $40 \mathrm{~g} / \mathrm{kg}$ DM of substrate (Eragrostis curvula hay) were evaluated for gas, $\mathrm{CH}_{4}$, and in vitro organic matter digestibility (IVOMD) in comparison with substrate alone. Gas kinetics were tested using a simple exponential model with lag. The results showed that compared with control, gas, $\mathrm{CH}_{4}$, IVOMD, $\mathrm{CH}_{4}$ /gas, $\mathrm{CH}_{4} / \mathrm{IVOMD}$, gas/IVOMD, asymptotic gas volume $(\mathrm{v})$, and rate of gas production $(\mathrm{k})$ decreased $(p<0.01)$ linearly with the increase in the inclusion levels of all tannin extracts. Also, ethyl acetate purified and pentanol purified tannin extracts reduced gas and $\mathrm{CH}_{4}$ at lower dosage (30 g/ $\left.\mathrm{kg} \mathrm{DM}\right)$ compared to unpurified tannin extract at a higher level $(40 \mathrm{~g} / \mathrm{kg})$. Pentanol purified tannin was more effective at lower dosage $(20 \mathrm{~g} / \mathrm{kg} \mathrm{DM})$ in terms of $\mathrm{CH}_{4} /$ gas and $\mathrm{CH}_{4} / \mathrm{IVOMD}$. It was concluded that the purification of mimosa tannin with ethyl acetate and pentanol reduced potential gas production and $\mathrm{CH}_{4}$ without much reduction in substrate digestibility when up to $30 \mathrm{~g} / \mathrm{kg}$ DM of feed was used. Lower inclusion levels of ethyl acetate and pentanol purified extracts could give a similar result with a higher dosage of unpurified tannin.

Keywords: digestibility; ethyl acetate; inclusion level; methane; mimosa tannin; pentanol; purification; Soxhlet 


\section{Introduction}

Recent research in ruminant nutrition gave more emphasis to enteric methane $\left(\mathrm{CH}_{4}\right)$ abatement strategies, because of its global warming potential, and the high impact it has on the animal industry. Enteric emissions account for about $39 \%$ of the agricultural contribution of global $\mathrm{CH}_{4}$ yield per annum [1], and are responsible for the loss of up to $12 \%$ of animal energy intake [2]. Several approaches were adopted to moderate $\mathrm{CH}_{4}$ production by ruminants, which include animal breeding; improved livestock production; feeding concentrates; antibiotics; and plant secondary compounds, particularly tannins and saponins [3]. However, the use of condensed tannins received more recent attention due to their availability, safety, and efficiency [4].

Mimosa (Acacia mearnsii) is regarded as a highly invasive and widely spread tanninrich legume; extending an area of over 2.5 million hectares [5], in addition to more than 130,000 hectares of commercial plantation [6]. Earlier research showed that mimosa tannin has the potential to reduce enteric $\mathrm{CH}_{4}$ and ammonia nitrogen $\left(\mathrm{NH}_{3} \mathrm{~N}\right)$ production, but with some negative effects on rumen fermentation and digestibility when supplemented above $50 \mathrm{~g} \mathrm{~kg}^{-1} \mathrm{DM}$ [7-9], attributed to the high amount of hydrolysable tannins, which are regarded as toxic to animals. For instance, when mimosa tannin was included at $\geq 50 \mathrm{~g} / \mathrm{kg}$ DM of substrate, in vitro $\mathrm{CH}_{4}$ and $\mathrm{NH}_{3} \mathrm{~N}$ reduced by $12 \%$ and $47 \%$, respectively; however, the proportion of total volatile fatty acids (VFAs) decreased (-6\%) compared to the control diet [9]. Similarly, reductions in enteric $\mathrm{CH}_{4}(-29 \%)$ and urine nitrogen $(-9 \%)$ were observed when higher amount of mimosa tannin extract was included in the diet of lactating cows, but milk yield dropped by $30 \%$ compared with the cows fed the control diet [8]. On the other hand, some studies reported little or no impact of mimosa tannin on rumen fermentation and methane mitigation when added below $50 \mathrm{~g} / \mathrm{kg}$ DM $[10,11]$. This is because mimosa tannin is not pure tannin phenolic [12]; it is composed of other non-tannin molecules [13-15], in the form of gums, simple sugars, and organic acids [16], which influence the bioactive properties of the tannin, making a lower dosage ineffective. Hence, there is the need for the purification of the mimosa tannin to remove the toxins and other non-tannin substances, thereby reducing the methane yield without compromising the normal rumen function.

Tannin purification is usually achieved with the use of Sephadex LH-20 [17-19]. However, the method is very costly and difficult to adopt by most laboratories [16]. Organic solvents, such as ethyl acetate and pentanol, are extensively utilized for extraction processes, coatings, and as carriers in the production of pharmaceuticals, flavorings, inks, adhesives, cosmetics, and antioxidants [20-22]. Recently, Missio et al. [16] reported an increase in tannin phenols at the expense of non-tannin compounds when mimosa tannin was purified with ethyl acetate and pentanol, using the simple and less expensive Soxhlet technique. However, to the best of knowledge, there is little or no information on the effect of ethyl acetate purified or pentanol purified mimosa tannin extracts in reducing enteric $\mathrm{CH}_{4}$ emission. The objectives of this study, therefore, were to purify the industrially extracted mimosa tannin with ethyl acetate and pentanol using the Soxhlet technique, to characterize the tannin constituents as influenced by the purification with organic solvents, and to evaluate the influence of adding various levels of ethyl acetate and pentanol purified tannin extracts on gas, methane, and in vitro organic matter digestibility of Eragrostis curvula hay.

\section{Materials and Methods}

\subsection{Study Area}

This investigation was carried out in the Department of Animal Science, University of Pretoria, South Africa. The area lies at $25^{\circ} 44^{\prime} 30^{\prime \prime}$ south and $28^{\circ} 15^{\prime} 30^{\prime \prime}$ east, at an elevation of $1360 \mathrm{~m}$ above sea level [23]. The study was reviewed and approved by the Animal Ethics Committee of the University of Pretoria (Ref No: EC075-17). 


\subsection{Materials}

The industrially extracted mimosa (Acacia mearnsii) tannin powder used in the current study was obtained from UCL Tannin Company Pty (Ltd), Kwa-Zulu Natal, South Africa. The extract was obtained from the bark of a Acacia mearnsii tree through a series of hot water extraction processes at a controlled temperature, pressure, and time, followed by vacuum evaporation and subsequent air-drying into fine powder before packaging and storage at $-4{ }^{\circ} \mathrm{C}$ [16]. The molecular weight of the mimosa ranged from 500-3000 Daltons [24]. The organic solvents used were: ethyl acetate and pentanol, procured from Sigma Aldrich, Johannesburg, South Africa. According to Missio et al. [16], pentanol has a polarity index of 0.568 , whereas ethyl acetate has a polarity index of 0.228 . Tannic acid, Folin-Ciocalteu reagent, butanol, and all other reagents used were of analytical grades supplied from Sigma Aldrich, Johannesburg, South Africa.

\subsection{Purification Process}

The purification of the mimosa tannin was carried out using the Soxhlet extraction technique as described by Missio et al. [16]. The samples (15 g) of mimosa tannin powder were weighed into thimbles, and fractionated separately with ethyl acetate and pentanol $(200 \mathrm{~mL})$ using a Soxhlet apparatus. The purifications were done at the boiling points of the solvents for $6 \mathrm{~h}$ (in triplicates). The ethyl acetate and pentanol purified tannin extracts were collected, oven dried at $70{ }^{\circ} \mathrm{C}$, and kept in a refrigerator before analysis.

\subsection{Tannin Characterization}

The powdered samples (200 mg) of unpurified and purified mimosa tannins with ethyl acetate and pentanol were weighed separately in $25 \mathrm{~mL}$ volume glass beakers. Aqueous acetone $(10 \mathrm{~mL})$ was added and suspended in an ultrasonic bath for $20 \mathrm{~min}$. The contents of the beakers were transferred into the centrifuge tubes, and kept in ice for $15 \mathrm{~min}$. The tubes were then centrifuged at $2500 \mathrm{rpm}$ for $15 \mathrm{~min}$, and the supernatants were collected and kept in ice prior to analysis. The Folin-Ciocalteu method was used to determine the concentrations of total phenols, non-tannin phenols, and total tannins as tannic acid equivalent [25], whereas the proportions of condensed tannins were obtained using the butanol-HCl technique as leucocyanidin equivalent, following the procedure of Porter et al. [26]. The concentration of hydrolysable tannin was calculated by differences between total tannins and condensed tannins according to the method of Singh et al. [27].

\subsection{Chemical Analysis of Substrate}

Freshly harvested Eragrostis curvula hay was procured from the Experimental Farm, University of Pretoria, and used as substrate. The sample was milled through a $2 \mathrm{~mm}$ screen, and evaluated for chemical composition. Dry matter (DM) and ash were determined according to the method of the Association of Official Analytical Chemists (AOAC) [28]. Nitrogen Analyzer (FP-2000, Leco Instrumente GmbH, Kirchheim, Germany) was used to analyze nitrogen content of the hay, and the value of nitrogen recorded was multiplied by 6.25 to get crude protein (CP). Fibre Analyzer (ANKOM 200/220, ANKOM Technology, New York, NY, USA) was utilized to determine the composition of neutral detergent fiber $(\mathrm{NDF})$, acid detergent fiber (ADF), and acid detergent lignin (ADL) of the substrates in sequence using the procedure of Van Soest et al. [29].

\subsection{In Vitro Incubation}

Buffer was formulated in a three-litres volumetric flask, placed in a water bath, and constantly flushed with saturated carbon di oxide $\left(\mathrm{CO}_{2}\right)$ at $39{ }^{\circ} \mathrm{C}$ for about 45 min, as described by Menke and Steingass [30], and modified by Mould et al. [31]. Rumen fluid was collected within the above 45 min period from three rumen fistulated Pinzyl steers fed with Eragrostis curvula hay and supplemented with Medicago sativa hay. The rumen fluid was squeezed through four folds of cheese cloth, taken to the laboratory without delay in a warmed thermos flask, and continuously flushed with $\mathrm{CO}_{2}$. Before incubation, the 
buffer solution was mixed with the rumen fluid at a ratio of 3:1 into a volumetric flask continuously flushed with $\mathrm{CO}_{2}$, and heated at $39^{\circ} \mathrm{C}$ in a water bath. The inoculum $(40 \mathrm{~mL})$ was then poured into $150 \mathrm{~mL}$ serum bottles, which already contained $400 \mathrm{mg}$ each of the substrate (Eragrostis curvula hay) mixed with $4 \mathrm{~mL}$ extracts of unpurified, and purified mimosa tannins with ethyl acetate and pentanol each of them at four different dosages $(10,20,30$, and $40 \mathrm{~g} / \mathrm{kg} \mathrm{DM})$. The serum bottles were immediately closed tightly using blue rubber stoppers with needles attached to three-way stopcocks, and then incubated at $39^{\circ} \mathrm{C}$, and shook at 120 revolutions per minute (rpm). All the treatments and control were replicated four times, and three blank bottles were included for correction in each incubation run, and four separate runs were conducted in a randomized complete block design (RCBD).

\subsubsection{Gas Estimation}

The in vitro gas volume produced during the fermentation process was calculated from pressure recorded in per square inch (psi) using a semi-automated pressure Transducer (PX4200-015GI; Omega Engineering Inc., Laval, QC, Canada) connected to a digital data logger (220 series indicators; Omega Engineering Inc.) [32]. The pressures built-up in the serum bottles at $3,6,12,24$, and $48 \mathrm{~h}$ of incubation were recorded by fitting the transducer into the upper tap of a three-way stopcock connected to the needle with a blue rubber stopper closing the fermentation bottle. The gas readings obtained from the bottles at each period (psi) were corrected by the subtraction of ambient pressure (psi) recorded by the data logger, and then converted to $\mathrm{mL}$ using the ANKOM technology equation [33], shown in Equation (1) below:

$$
V_{x}=V_{j} P_{p s i} \times 0.068004084
$$

where, $V_{x}=$ volume of gas in $\mathrm{mL}, V_{j}=$ headspace of serum bottle in $\mathrm{mL}$, and $P_{p s i}=$ corrected pressure recorded in psi by the data logger.

\subsubsection{Methane Determination}

Methane analysis was performed according to the method of Tavendale et al. [34]. Immediately after reading the pressure built-up in the bottles at 3, 6, 12, 24, and $48 \mathrm{~h}$ of incubation periods, gas samples were taken in $10 \mathrm{~mL}$ luer-locked syringes, and injected manually into the gas chromatography (SRI GC 8610C BTU Gas Analyzer System, Bad Honnef, Germany) fitted with a flame ionization sensor, and standardized with methane and carbon di oxide following the procedure of Gemeda and Hassen [10]. Methane concentrations were estimated from the area covered by the gas samples in the SRI GC using a standard methane curve.

\subsection{In Vitro Organic Matter Digestibility Determination (IVOMD)}

The IVOMD of Eragrostis curvula hay after inclusion of unpurified mimosa tannin, and mimosa tannins purified with ethyl acetate and pentanol at 10, 20,30, and $40 \mathrm{~g} / \mathrm{kg}$ DM was assessed using two stage digestion processes, as described by Tilley and Terry [35], with the modifications of Engels and Van der Merwe [36]. Artificial saliva was prepared in a two-litre volumetric flask, kept in a water bath heated at $39^{\circ} \mathrm{C}$, and flushed with saturated $\mathrm{CO}_{2}$ continuously. Rumen fluid was obtained from three donor cannulated Pinzyl steers fed with Eragrostis curvula hay and supplemented with Medicago sativa hay. The rumen fluid was mixed with artificial saliva at a ratio of $1: 3$, and heated at $39^{\circ} \mathrm{C}$ in a water bath with continuous flushing with $\mathrm{CO}_{2}$. In stage one, the saliva and rumen fluid mixtures $(20 \mathrm{~mL})$ were splashed into digestion tubes, which already contained $200 \mathrm{mg}$ each of the substrate and $2 \mathrm{~mL}$ each of urea and tannin extracts (unpurified, ethyl acetate purified, or pentanol purified) at four different concentrations (10, 20,30, and $40 \mathrm{~g} / \mathrm{kg}$ DM of feed). The tubes were immediately closed tightly using stoppers fitted with marbles, and digested for $48 \mathrm{~h}$ at $39^{\circ} \mathrm{C}$, and shook at $100 \mathrm{rpm}$. After $48 \mathrm{~h}$, all the tubes were centrifuged at $2500 \mathrm{rpm}$ for $15 \mathrm{~min}$, and the supernatants were carefully removed. In stage two, acid-pepsin solutions $(20 \mathrm{~mL})$ were added into the tubes, and digested for another $48 \mathrm{~h}$ at $39^{\circ} \mathrm{C}$ and $100 \mathrm{rpm}$. 
The tubes were removed and centrifuged again at $2500 \mathrm{rpm}$ for $15 \mathrm{~min}$. The supernatants obtained were oven dried at $105^{\circ} \mathrm{C}$ for $18 \mathrm{~h}$. The dried supernatants were weighed and ashed at $550{ }^{\circ} \mathrm{C}$ in a muffle furnace for three hours. The IVOMD of the substrate was evaluated from the weights of the initial samples, oven dried, and the ash left over. All the treatments and control were in triplicates, three blank tubes were added for correction within each run, and four separate digestion runs were done in RCBD.

\subsection{Statistical Analysis}

All statistical analyses were performed using the general linear model procedure of SAS 9.4 (SAS Institute Inc., Cary, NC, USA). Data on mimosa tannin characterization were analyzed using a one-way ANOVA. Where significant differences existed, means were separated using LSD. Gas production kinetics were evaluated using the Schofield [37] simple exponential Equation (2).

$$
V_{t}=v *\left(1-e^{(-k *(t-l))}\right)
$$

where $V_{t}=$ volume of gas at $t=$ time; $v=$ asymptotic gas volume corresponding to complete substrate digestion; $k=$ rate constant; $l=$ discrete lag time before gas production commences.

For gas, methane, and in vitro organic matter digestibility, and their ratios and gas kinetics $(v, k$, and $l)$, the experimental design was a randomized complete block design. The statistical model adopted for the analysis is stated in Equation (3) below:

$$
y_{i j k}=\mu+\text { Block }+T_{i}+L_{j}+(T L)_{i j}+\varepsilon_{i j k}
$$

where $y_{i j k}=$ observation $\mathrm{k}$ for various mimosa tannin extracts, $T$ (i; unpurified, ethyl acetate purified and pentanol purified), and level of inclusion, $L$ (j; 10, 20, 30, and $40 \mathrm{~g} / \mathrm{kg} \mathrm{DM}$ ), of the extracts, $\mu=$ overall mean, Block = blocking effect (incubation runs), $T_{i}=$ effect of mimosa tannin extract, $L_{j}=$ effect of inclusion level, $(T L)_{i j}=$ effect of interaction between tannin extract and inclusion level, and $\varepsilon_{i j k}=$ random error. Significantly different means for unpurified and purified tannin extracts were separated using Tukey's test. For each tannin extract, single degrees of freedom orthogonal polynomial contrasts (linear, quadratic, and cubic) were used to test the effect of the inclusion level of tannin extracts.

\section{Results and Discussion}

\subsection{Characterization of Unpurified and Purified Mimosa Tannins}

Figure 1 shows tannin characterization for unpurified and purified mimosa tannins. The results indicated that the purification of mimosa tannin with ethyl acetate and pentanol did not influence $(p>0.05)$ the concentration of total phenol (TP), non-tannin phenol (NTP), total tannin (TT), and hydrolysable tannin (HT). However, ethyl acetate purified and pentanol purified extracts had $(p<0.05)$ higher proportion $(278.1 \mathrm{~g} / \mathrm{kg}$ vs. $261.5 \mathrm{~g} / \mathrm{kg}$ $\mathrm{DM})$ of condensed tannin (CT) compared with purified tannin (221.7 g/ $\mathrm{kg} \mathrm{DM})$. In general, the Soxhlet purification of the mimosa tannin with organic solvents did not affect any of the parameters measured except condensed tannins, which increased by $26 \%$ after purification with ethyl acetate and $18 \%$ with pentanol. This suggests that ethyl acetate-being relatively polar solvent, with a lower boiling temperature-has stronger affinity to the CT constituent of the mimosa tannin. The concentration of $\mathrm{CT}$ has been shown to decrease with an increase in the polarity of solvents [16]. The proportion of CT recorded in this study for both ethyl acetate purified and pentanol purified mimosa extracts were higher than the $150 \mathrm{~g}$ of CT kg ${ }^{-1}$ DM reported by Minho et al. [38], and Bhatta et al. [39], as well as the $235 \mathrm{~g} / \mathrm{kg}$ DM obtained by Kardel et al. [40], for unpurified mimosa tannin. However, Grainger et al. [8], Carulla et al. [7], and Hassanat and Benchaar [9] reported higher concentrations of CT (603, 615 , and $820 \mathrm{~g} \mathrm{~kg}^{-1} \mathrm{DM}$, respectively) after purification of mimosa tannin with a more advanced Sephadex LH-20. Missio et al. [16] suggested that Sephadex LH-20 involves complex analytical procedures and an expensive apparatus; thus, it is difficult to adopt in most laboratories. 


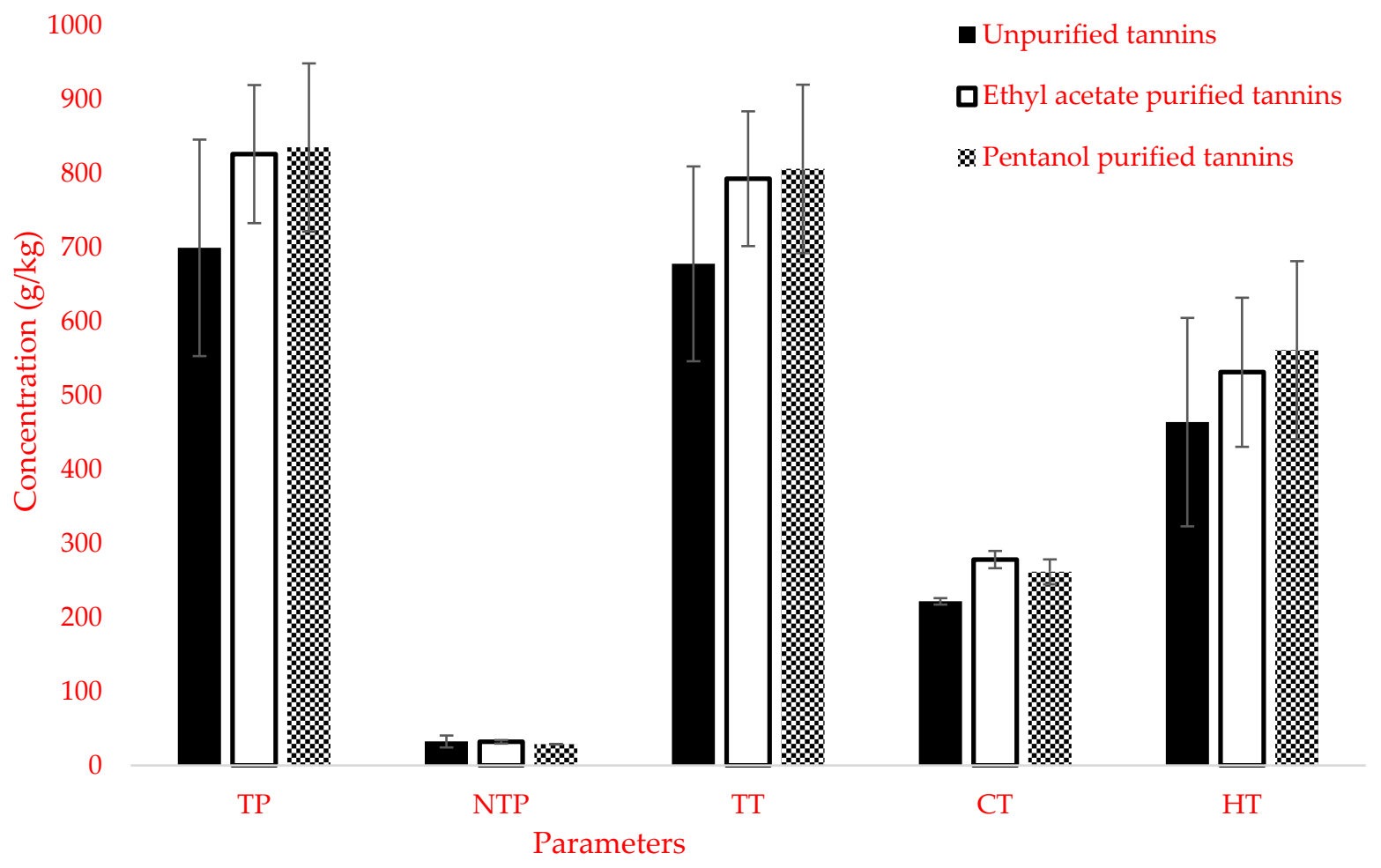

Figure 1. Characterization of unpurified and purified mimosa tannin with ethyl acetate and pentanol. $\mathrm{TP}=$ total phenols, NTP $=$ non-tannin phenols, $\mathrm{TT}=$ total tannin, $\mathrm{CT}=$ condensed tannin, and $\mathrm{HT}=$ hydrolysable tannin.

\subsection{Gas, Methane and In Vitro Organic Matter Digestibility}

The substrate (Eragrostis curoula hay) used in the current study constituted the following: DM (912.1 g/ kg), ash (50 g/ kg), CP (78.5 g/ kg), NDF (698.4 g/ kg), ADF (396.1 g/kg), and ADL $(59.3 \mathrm{~g} / \mathrm{kg})$. The chemical composition showed that the substrate had high fiber and low crude protein, which favors a higher production of hydrogen gas $\left(\mathrm{H}_{2}\right)$, utilized by methanogens to reduce $\mathrm{CO}_{2}$ to $\mathrm{CH}_{4}$. The current study aimed at examining the effects of unpurified, ethyl acetate purified, and pentanol purified mimosa tannins on suppressing enteric methane production in relation to dry matter digestibility of the substrate.

Table 1 present the summary of gas, methane, and in vitro organic matter digestibility from Eragrostis curvula hay after the inclusion of various levels of unpurified, ethyl acetate purified, and pentanol purified mimosa tannin extracts. The results indicated that gas, $\mathrm{CH}_{4}$, and IVOMD reduced at a decreasing rate (linear $p<0.01$ ) with increasing levels of both purified and non-purified mimosa tannins compared to substrate alone. Compared to control, unpurified and purified tannin extracts reduced gas $(p<0.01)$ at $20-40 \mathrm{~g} / \mathrm{kg}$ dosages, whereas a significant decrease in $\mathrm{CH}_{4}$ was observed only at the $40 \mathrm{~g} / \mathrm{kg}$ inclusion level. However, the IVOMD of Eragrostis curvula hay was affected by all the dosages of both unpurified and purified mimosa tannin extracts. The simple effect of tannin type revealed significant effects of unpurified, ethyl acetate purified, and pentanol purified mimosa tannin extracts on $\mathrm{CH}_{4}$ and IVOMD. However, gas volume was not influenced by tannin type $(p>0.05)$. Moreover, inclusion levels reduced gas, $\mathrm{CH}_{4}$, and IVOMD $(p<0.01)$ for all the tannin extracts. However, there were no interaction effects $(p>0.05)$ between tannin extracts and inclusion level on gas and $\mathrm{CH}_{4}$, whereas IVOMD showed a tendency for tannin extract and dosage interaction. 
Table 1. Gas, methane $\left(\mathrm{CH}_{4}\right)$ and in vitro organic matter digestibility (IVOMD) from Eragrostis curvula hay incubated with various levels of unpurified, ethyl acetate purified, and pentanol purified mimosa tannin extracts.

\begin{tabular}{|c|c|c|c|c|}
\hline Tannin Extracts & Level (g/kg DM) & Gas (mL/g DM) & $\begin{array}{c}\text { Parameters } \\
\mathrm{CH}_{4}(\mathrm{~mL} / \mathrm{g} \mathrm{DM})\end{array}$ & IVOMD (g/kg) \\
\hline \multirow{9}{*}{ Unpurified Tannin } & 0 & $155.2^{\mathrm{a}}$ & $7.9^{a}$ & $600.7^{a}$ \\
\hline & 10 & $149.8^{\mathrm{ab}}$ & $7.4^{\mathrm{ab}}$ & $592.5^{b c}$ \\
\hline & 20 & $145.0^{b c}$ & $7.1^{\mathrm{ab}}$ & $592.9^{b}$ \\
\hline & 30 & $142.5^{\mathrm{c}}$ & $6.8^{\mathrm{ab}}$ & $589.0^{b c}$ \\
\hline & 40 & $138.2^{c}$ & $6.2^{b}$ & 582.5 def \\
\hline & SEM & 1.59 & 0.33 & 14.50 \\
\hline & Linear & $<0.0 .01$ & 0.01 & $<0.01$ \\
\hline & Quadratic & 0.45 & 0.95 & 0.99 \\
\hline & Cubic & 0.65 & 0.65 & 0.81 \\
\hline \multirow{9}{*}{$\begin{array}{l}\text { Ethyl acetate purified } \\
\text { Tannin }\end{array}$} & 0 & $155.2^{\mathrm{a}}$ & $7.9^{a}$ & $600.7^{a}$ \\
\hline & 10 & $150.1^{\mathrm{ab}}$ & $7.3^{\mathrm{ab}}$ & $592.9^{b}$ \\
\hline & 20 & $144.5^{b c}$ & $6.9^{a b}$ & $584.7^{\text {cde }}$ \\
\hline & 30 & $139.7^{\mathrm{cd}}$ & $6.3^{a b}$ & $582.4^{\mathrm{def}}$ \\
\hline & 40 & $137.3^{d}$ & $6.1^{b}$ & $576.3^{f}$ \\
\hline & SEM & 1.63 & 0.41 & 13.73 \\
\hline & Linear & $<0.01$ & 0.01 & $<0.01$ \\
\hline & Quadratic & 0.33 & 0.73 & 0.86 \\
\hline & Cubic & 0.58 & 0.94 & 0.94 \\
\hline \multirow{9}{*}{$\begin{array}{l}\text { Pentanol purified } \\
\text { Tannin }\end{array}$} & 0 & $155.2^{\mathrm{a}}$ & $7.9^{a}$ & $600.7^{a}$ \\
\hline & 10 & $149.4^{\mathrm{ab}}$ & $7.1^{\mathrm{ab}}$ & $592.5^{b c}$ \\
\hline & 20 & $143.7^{b c}$ & $6.6^{\mathrm{ab}}$ & $585.4^{\text {cde }}$ \\
\hline & 30 & $141.5^{c}$ & $6.40^{\mathrm{ab}}$ & 582.0 def \\
\hline & 40 & $139.6^{c}$ & $6.1^{\mathrm{b}}$ & $578.9^{\text {ef }}$ \\
\hline & SEM & 1.43 & 0.39 & 13.84 \\
\hline & Linear & $<0.0 .01$ & 0.01 & $<0.01$ \\
\hline & Quadratic & 0.05 & 0.42 & 0.79 \\
\hline & Cubic & 0.96 & 0.77 & 0.98 \\
\hline SEM & & 0.414 & 0.387 & 0.696 \\
\hline \multicolumn{5}{|l|}{$p$ values } \\
\hline $\mathrm{T}$ & & 0.25 & $<0.01$ & $<0.01$ \\
\hline L & & $<0.01$ & $<0.01$ & $<0.01$ \\
\hline $\mathrm{T}^{*} \mathrm{~L}$ & & 0.25 & 0.10 & 0.05 \\
\hline
\end{tabular}

For each tannin extract means with different superscripts $(a, b, c, d, e, f)$ within a column differ significantly at $p<0.05 . \mathrm{SEM}=$ standard error of mean, $\mathrm{T}=$ tannin extract, $\mathrm{L}=$ level of inclusion, $\mathrm{T}^{*} \mathrm{~L}=$ interaction effect between tannin extracts and inclusion level.

Generally, the inclusion of $40 \mathrm{~g} / \mathrm{kg}$ DM of ethyl acetate purified and pentanol purified tannins reduced $\mathrm{CH}_{4}$ by approximately $23 \%$ each, whereas unpurified extract reduced $\mathrm{CH}_{4}$ by $21 \%$ at a similar dosage, with little effect on substrate digestibility. The effect of unpurified and purified tannin extracts recorded in this study could be connected to their interference with the proliferation and activities of methanogens. It has been well documented that condensed tannins reduced enteric methane either directly by hindering the activities of methanogenic bacteria, or indirectly by reducing organic matter digestibility [41-45]. This finding is in agreement with that of Hassanat and Benchaar [9], who reported more reduction in gas and $\mathrm{CH}_{4}$ with an increase in the concentration of $A$. mearnsii tannin extracts. Tan et al. [46] also reported that increasing levels of Leucaena leucocephala CTs in the range of 20 to $60 \mathrm{~g} / \mathrm{kg}$ DM decreased gas, $\mathrm{CH}_{4}$, and IVOMD.

Ethyl acetate purified and pentanol purified tannin extracts reduced more $\mathrm{CH}_{4}$ yield than unpurified tannin extract at a similar inclusion level. This could be attributed to the purification effects, which showed a significant increase in condensed tannin concentration for ethyl acetate purified extract. In corroboration with our finding, Tan et al. [46] reported 
$\mathrm{CH}_{4}$ reduction (-33\%) at lower concentrations $\left(20 \mathrm{~g} \mathrm{~kg}^{-1} \mathrm{DM}\right)$ of L. leucocephala extracts purified using Sephadex LH-20. However, Hassanat and Benchaar [9] reported $9 \%$ and $12 \%$ reductions in gas and $\mathrm{CH}_{4}$, respectively, for unpurified mimosa extract at $50 \mathrm{~g} / \mathrm{kg}$ dosage, which are lower than the values obtained in this study for ethyl acetate and pentanol purified tannins at a $40 \mathrm{~g} / \mathrm{kg}$ DM inclusion level. Similarly, Adejoro et al. [24] obtained about a $20 \%$ decrease in gas and $24 \%$ decrease in $\mathrm{CH}_{4}$ after the inclusion of $42 \mathrm{~g} / \mathrm{kg}$ $\mathrm{DM}$ of mimosa tannin extract, which is similar with the percentage reduction recorded in the present study for ethyl acetate purified tannin at a $40 \mathrm{~g} / \mathrm{kg}$ DM concentration. Carulla et al. [7] also reported around a $13 \%$ decrease in $\mathrm{CH}_{4}$ at a $25 \mathrm{~g} / \mathrm{kg}$ DM inclusion level of unpurified mimosa tannin, which is similar to the proportion obtained for pentanol purified tannin, but below that of ethyl acetate purified extract at $20 \mathrm{~g} / \mathrm{kg}$ DM.

The ratios of gas, methane, and in vitro organic matter digestibility from Eragrostis curvula hay supplemented with different levels of unpurified and purified mimosa tannin extracts is summarized in Table 2. The results showed that increases in dosages of purified and non-purified mimosa tannin extracts decreased $\mathrm{CH}_{4}$ per unit gas, $\mathrm{CH}_{4}$ per unit IVOMD, and gas per unit IVOMD linearly $(p>0.01)$ compared to substrate alone. When compared with the control, unpurified tannin extract mainly reduced $(p<0.01) \mathrm{CH}_{4} /$ gas and $\mathrm{CH}_{4} / \mathrm{IVOMD}$ at a $40 \mathrm{~g} / \mathrm{kg}$ DM concentration, whereas ethyl acetate purified extract had a significant effect on $\mathrm{CH}_{4} /$ gas and $\mathrm{CH}_{4} / \mathrm{IVOMD}$ at a $30-40 \mathrm{~g} / \mathrm{kg}$ DM inclusion level, and $\mathrm{CH}_{4} /$ gas and $\mathrm{CH}_{4} / \mathrm{IVOMD}$ were influenced $(p<0.01)$ by the addition of $20-40 \mathrm{~g} / \mathrm{kg}$ DM of pentanol purified tannin. For gas/IVOMD, both unpurified and purified mimosa tannins had significant effects at 20-40 g/ $\mathrm{kg}$ DM dosages compared with the control.

The main effect of tannin extract revealed a significant effect of unpurified and purified mimosa tannin extracts on $\mathrm{CH}_{4}$ /gas and $\mathrm{CH}_{4} /$ IVOMD. However, gas/IVOMD was not affected $(p>0.05)$ by the purification. Furthermore, a simple effect of tannin concentrations showed that levels of inclusion influenced $\mathrm{CH}_{4}$ /gas, $\mathrm{CH}_{4} /$ IVOMD, and gas/IVOMD significantly. There was no significant interaction effect between mimosa tannin type and level of inclusion for $\mathrm{CH}_{4}$ per unit gas, $\mathrm{CH}_{4}$ per unit IVOMD, and gas per unit IVOMD of the substrate.

In general, the volume of $\mathrm{CH}_{4}$ per unit gas, $\mathrm{CH}_{4}$ per unit IVOMD, and gas per unit IVOMD decreased with the increase in the concentrations of unpurified and purifed tannin extracts. Moreover, similar inclusion levels of ethyl acetate purified and pentanol purified mimosa extracts had lower $\mathrm{CH}_{4} /$ gas, $\mathrm{CH}_{4} / \mathrm{IVOMD}$, and gas/IVOMD compared to unpurified tannin. Pentanol purified tannin was more effective at lower dosage in terms of $\mathrm{CH}_{4} /$ gas, $\mathrm{CH}_{4} / \mathrm{IVOMD}$. This suggested that the anti-methanogenic effect of purified tannin extracts was more prominent than their relative effect on organic matter digestibility. This could be linked to the relative increases in CT concentrations due to the purification effects. Condensed tannins have been shown to slow down the activities of microorganisms, as well as the rate of fiber and organic matter degradation, which, in turn, reduces the volume of hydrogen gas $\left(\mathrm{H}_{2}\right)$ required by methanogens to produce $\mathrm{CH}_{4}$ [2]. In concurrence with our results, previous in vitro studies also reported a significant reduction in $\mathrm{CH}_{4}$ /gas, $\mathrm{CH}_{4}$ /IVOMD, and gas/IVOMD when some tannin rich browse plants [10], and medicinal plant extracts were incubated together with Eragrostis curvula hay [47,48].

Table 3 presents the effect of various inclusion levels of unpurified, ethyl acetate purified, and pentanol purified mimosa tannin extracts on gas production indices. The results revealed that the asymptotic gas volume (v) and rate of gas production $(\mathrm{k})$ reduced at a decreasing rate (linear, $p>0.01$ ) with increasing levels of unpurified, ethyl acetate purified, and pentanol purified mimosa tannin extracts compared to control. However, compared with control, the lag term (l) was not affected by all the mimosa tannin inclusion levels. Compared with control, though the inclusion of unpurified tannin resulted in lower ' $\mathrm{v}$ ' and ' $\mathrm{k}$ ' at a $40 \mathrm{~g} / \mathrm{kg}$ dosage, ethyl acetate purified and pentanol purified extract affected ' $v$ ' and ' $k$ ' at 30-40 g/kg levels. The simple effect of tannin extracts showed a significant effect of purification on ' $v$ '. However, ' $k$ ' and ' 1 ' were not affected by tannin types $(p>0.05)$. Likewise, inclusion levels reduced ' $v$ ' and ' $k$ ' $(p<0.01)$ with the exception of ' 1 '. Though 
there was no interaction effect $(p>0.05)$ between tannin extracts and dosages on ' $k$ ' and ' 1 ', mimosa extracts and inclusion levels interaction affected ' $\mathrm{v}$ ' significantly.

Table 2. The ratios of gas, $\mathrm{CH}_{4}$, and IVOMD from Eragrostis curvula hay incubated with various levels of unpurified, ethyl acetate purified, and pentanol purified mimosa tannin extracts.

\begin{tabular}{|c|c|c|c|c|}
\hline Tannin Extracts & Level (g/kg DM) & $\mathrm{CH}_{4} / \mathrm{Gas}$ & $\begin{array}{c}\text { Parameters } \\
\mathrm{CH}_{4} / \mathrm{IVOMD}(\mathrm{mL} / \mathrm{kg})\end{array}$ & Gas/IVOMD (mL/kg) \\
\hline \multirow{9}{*}{ Unpurified tannin } & 0 & $0.051^{\mathrm{a}}$ & $0.013^{a}$ & $0.259^{a}$ \\
\hline & 10 & $0.050 \mathrm{ab}$ & $0.013^{\mathrm{a}}$ & $0.254^{\mathrm{ab}}$ \\
\hline & 20 & $0.049^{a b c}$ & $0.012^{a b}$ & $0.245^{b-e}$ \\
\hline & 30 & $0.048^{\mathrm{a}-\mathrm{d}}$ & $0.012^{\mathrm{ab}}$ & $0.243^{\mathrm{de}}$ \\
\hline & 40 & $0.045^{\mathrm{de}}$ & $0.011^{\mathrm{b}}$ & $0.238^{\mathrm{e}}$ \\
\hline & SEM & 0.002 & 0.005 & 0.008 \\
\hline & Linear & $<0.01$ & 0.003 & $<0.01$ \\
\hline & Quadratic & 0.724 & 0.793 & 0.832 \\
\hline & Cubic & 0.732 & 0.877 & 0.969 \\
\hline \multirow{9}{*}{$\begin{array}{l}\text { Ethyl acetate purified } \\
\text { tannin }\end{array}$} & 0 & $0.051^{\mathrm{a}}$ & $0.013^{a}$ & $0.259^{a}$ \\
\hline & 10 & $0.049^{a b c}$ & $0.012^{a b}$ & $0.254^{\mathrm{ab}}$ \\
\hline & 20 & $0.048^{\mathrm{a}-\mathrm{d}}$ & $0.012^{\mathrm{ab}}$ & $0.248^{b c d}$ \\
\hline & 30 & $0.045^{\mathrm{de}}$ & $0.011^{b}$ & $0.240^{\mathrm{de}}$ \\
\hline & 40 & $0.044^{\mathrm{e}}$ & $0.011^{b}$ & $0.239 \mathrm{e}$ \\
\hline & SEM & 0.003 & 0.001 & 0.008 \\
\hline & Linear & $<0.01$ & 0.010 & $<0.01$ \\
\hline & Quadratic & 0.959 & 0.837 & 0.864 \\
\hline & Cubic & 0.951 & 0.808 & 0.784 \\
\hline \multirow{9}{*}{$\begin{array}{l}\text { Pentanol purified } \\
\text { tannin }\end{array}$} & 0 & $0.051^{\mathrm{a}}$ & $0.013^{a}$ & $0.259^{a}$ \\
\hline & 10 & $0.048^{\mathrm{a}-\mathrm{d}}$ & $0.012^{a b}$ & $0.253^{a b c}$ \\
\hline & 20 & $0.046^{\text {cde }}$ & $0.011^{b c}$ & $0.246^{\mathrm{b}-\mathrm{e}}$ \\
\hline & 30 & $0.045^{\mathrm{de}}$ & $0.011^{b c}$ & $0.244^{\text {cde }}$ \\
\hline & 40 & $0.044^{\mathrm{e}}$ & $0.010^{\mathrm{c}}$ & $0.242^{\mathrm{e}}$ \\
\hline & SEM & 0.003 & 0.001 & 0.008 \\
\hline & Linear & $<0.01$ & 0.007 & $<0.01$ \\
\hline & Quadratic & 0.669 & 0.688 & 0.700 \\
\hline & Cubic & 0.822 & 0.721 & 0.955 \\
\hline SEM & & 0.0003 & 0.0001 & 0.0008 \\
\hline \multicolumn{5}{|l|}{$p$-values } \\
\hline $\mathrm{T}$ & & $<0.01$ & 0.01 & 0.48 \\
\hline L & & $<0.01$ & $<0.01$ & $<0.01$ \\
\hline $\mathrm{T}^{*} \mathrm{~L} 2$ & & 0.59 & 0.40 & 0.46 \\
\hline
\end{tabular}

For eaqch tannin extract means with different superscripts $(\mathrm{a}, \mathrm{b}, \mathrm{c}, \mathrm{d}, \mathrm{e})$ within a column differ significantly at $p<0.05 . \mathrm{SEM}=$ standard error of mean, $\mathrm{T}=$ tannin extract, $\mathrm{L}=$ level of inclusion, $\mathrm{T}^{*} \mathrm{~L}=$ interaction effect between tannin extracts and inclusion level.

Generally, potential gas production, as a result of complete substrate digestion and rate of gas production, decreased with the increase in the concentrations of mimosa tannin extracts. Moreover, a similar concentration of purified tannins resulted in lower ' $v$ ' and ' $k$ ' compared to the unpurified tannin extract.

Lower asymptotic gas production from in vitro fermentation is linked to a slow rate of organic matter degradation in the rumen [49]. A slow rate of gas production has been attributed to the presence of hydrolysable tannins in mimosa extract, which are believed to be poisonous to rumen microorganisms [50]. However, the anti-methanogenic effect of tannins involves a mixture of direct toxicity on the methanogens, or an indirect reduction in fiber and organic matter degradation [42,50]. The asymptotic gas volume $(\mathrm{mL} / \mathrm{g})$ and rate of gas production $\left(\mathrm{h}^{-1}\right)$ obtained in the current study were lower than the $20.2 \mathrm{~mL}$ vs. $24.7 \mathrm{~mL}$, and $10.9 \%$ vs. $12 \%$ per $100 \mathrm{mg}$ DM, reported by Schofield and Pell [51], and Mir et al. [52], for alfalfa and fenugreek, respectively. In addition, longer lag time was 
recorded by Mir et al. [52] compared to the values obtained in this study. These could be attributed to the variation in chemical composition, particularly the differences in fiber and protein content.

Table 3. The gas production kinetics from Eragrostis curvula hay incubated with various levels of unpurified, ethyl acetate purified, and pentanol purified mimosa tannin extracts.

\begin{tabular}{|c|c|c|c|c|}
\hline Tannin Extracts & Level (g/kg DM) & v (mL/g DM) & $\begin{array}{c}\text { Parameters } \\
\text { k (mL/h) }\end{array}$ & 1 (h) \\
\hline \multirow{9}{*}{ Unpurified tannin } & 0 & $195.7^{a}$ & $0.034^{\mathrm{a}}$ & 0.017 \\
\hline & 10 & $193.6^{a}$ & $0.032^{a b}$ & 0.079 \\
\hline & 20 & $188.6^{\mathrm{ab}}$ & $0.031^{\mathrm{ab}}$ & 0.221 \\
\hline & 30 & $187.9^{a b}$ & $0.031^{\mathrm{ab}}$ & 0.249 \\
\hline & 40 & $180.7^{b}$ & $0.030^{b}$ & 0.086 \\
\hline & SEM & 3.566 & 0.002 & 0.171 \\
\hline & Linear & 0.007 & 0.022 & 0.578 \\
\hline & Quadratic & 0.659 & 0.495 & 0.394 \\
\hline & Cubic & 0.749 & 1.000 & 0.626 \\
\hline \multirow{9}{*}{$\begin{array}{l}\text { Ethyl acetate purified } \\
\text { tannin }\end{array}$} & 0 & $195.7^{a}$ & $0.034^{\mathrm{a}}$ & 0.017 \\
\hline & 10 & $192.5^{\mathrm{ab}}$ & $0.032^{a b}$ & 0.150 \\
\hline & 20 & $186.7^{a b}$ & $0.031^{\mathrm{ab}}$ & 0.238 \\
\hline & 30 & $182.7^{\mathrm{b}}$ & $0.030^{\mathrm{b}}$ & 0.177 \\
\hline & 40 & $180.4^{b}$ & $0.030^{b}$ & 0.144 \\
\hline & SEM & 2.881 & 0.001 & 0.158 \\
\hline & Linear & 0.001 & 0.02 & 0.585 \\
\hline & Quadratic & 0.748 & 0.640 & 0.429 \\
\hline & Cubic & 0.636 & 0.911 & 0.885 \\
\hline \multirow{9}{*}{$\begin{array}{l}\text { Pentanol purified } \\
\text { tannin }\end{array}$} & 0 & $195.7^{a}$ & $0.034^{a}$ & 0.017 \\
\hline & 10 & $192.1^{\mathrm{ab}}$ & $0.032^{a b}$ & 0.255 \\
\hline & 20 & $187.6^{\mathrm{ab}}$ & $0.031^{\mathrm{ab}}$ & 0.132 \\
\hline & 30 & $187.4^{\mathrm{b}}$ & $0.030^{\mathrm{b}}$ & 0.087 \\
\hline & 40 & $186.7^{b}$ & $0.029^{b}$ & 0.083 \\
\hline & SEM & 2.700 & 0.001 & 0.191 \\
\hline & Linear & 0.024 & 0.022 & 0.551 \\
\hline & Quadratic & 0.220 & 0.813 & 0.318 \\
\hline & Cubic & 0.769 & 0.779 & 0.701 \\
\hline SEM & & 0.703 & 0.0003 & 0.039 \\
\hline \multicolumn{5}{|l|}{$p$-values } \\
\hline $\mathrm{T}$ & & 0.02 & 0.43 & 0.32 \\
\hline L & & $<0.01$ & 0.01 & 0.11 \\
\hline $\mathrm{T}^{*} \mathrm{~L}$ & & 0.03 & 0.73 & 0.26 \\
\hline
\end{tabular}

For each tannin extract means with different superscripts $\left({ }^{(a},{ }^{b}\right)$ within a column differ significantly at $p<0.05$. SEM = standard error of mean, $\mathrm{T}=$ tannin extract, $\mathrm{L}=$ level of inclusion, $\mathrm{T} * \mathrm{~L}=$ interaction effect between tannin extracts and inclusion level, $\mathrm{v}=$ asymptotic gas volume, $\mathrm{k}=$ rate constant, $\mathrm{l}=$ discrete lag term.

\section{Conclusions}

The findings of this study showed that the Soxhlet purification of mimosa tannin with ethyl acetate and pentanol increased the condensed tannin concentration. However, the highest increase in condensed tannin was achieved by using ethyl acetate. Gas, methane, and in vitro organic matter digestibility of Eragrostis curvula hay, and their ratios, decreased with the increase in the inclusion levels of unpurified, ethyl acetate purified, and pentanol purified mimosa tannin extracts. Pentanol purified tannin was more effective at lower dosage in terms of $\mathrm{CH}_{4}$ /gas, $\mathrm{CH}_{4}$ /IVOMD. Similarly, asymptotic gas volume and rate of gas production reduced with the increase in the concentration of tannin extracts. Ethyl acetate and pentanol purified mimosa extracts reduced gas and methane volume at a lower dosage (30 g/kg DM) compared to unpurified tannin, which has similar efficacy at a higher level $(40 \mathrm{~g} / \mathrm{kg})$. It was concluded that the purification of mimosa tannin with ethyl acetate 
and pentanol reduced potential gas production and $\mathrm{CH}_{4}$ with little impact on digestibility when up to $30 \mathrm{~g} / \mathrm{kg}$ DM of feed was used. Lower inclusion levels of ethyl acetate purified and pentanol purified extracts could give the same effect with higher concentrations of unpurified tannin extract.

Author Contributions: S.L.I. and A.H. developed the hypothesis and designed the experiments, whereas data collection and analysis were done by S.L.I., A.H. and S.L.I. collaborated in the statistics and interpretation of the results. S.L.I. wrote the initial draft of this manuscript, whereas A.H. reviewed and modified it. Funding acquisition, A.H. All authors have read and agreed to the published version of the manuscript.

Funding: Running cost of the research was funded by the National Research Foundation, South Africa under grant No 118518, and the University of Pretoria awarded a PhD research bursary to the first author.

Institutional Review Board Statement: This research was approved by the Animal Ethics Committee of the University of Pretoria (Ref No: EC075-17).

Data Availability Statement: Data contained within the article are available on request from the authors.

Acknowledgments: The authors thank the National Research Foundation (Grant no 118518), South Africa, for funding the research, and the University of Pretoria for a research bursary award to the first author.

Conflicts of Interest: The authors declare no conflict of interest.

\section{References}

1. Gerber, P.J.; Steinfeld, H.; Henderson, B.; Mottet, A.; Opio, C.; Dijkman, J.; Falcucci, A.; Tempio, G. Technical options for the mitigation of direct methane and nitrous oxide emissions from livestock: A review. Animal 2013, 7, 220-234. [CrossRef] [PubMed]

2. Piñeiro-Vázqueza, A.T.; Canul-Solísa, J.R.; Alayón-Gamboab, J.A.; Chay-Canulc, A.J.; Ayala-Burgosa, A.J. Potential of condensed tannins for the reduction of emissions of enteric methane and their effect on ruminant productivity. Arch. Med. Vet. 2015, 47, 263-272. [CrossRef]

3. Eckard, R.J.; Grainger, C.; de Klein, C.A.M. Options for the abatement of methane and nitrous oxide from ruminant production: A review. Livest. Sci. 2010, 130, 47-56. [CrossRef]

4. Martin, C.; Morgavi, D.P.; Doreau, M. Methane mitigation in ruminants: From microbe to the farm scale. Animal 2010, 4, 351-365. [CrossRef]

5. de Wit, M.P.; Crookes, D.J.; Van Wilgen, B.W. Conflicts of interest in environmental management: Estimating. Biol. Invasions 2001, 3, 167-178. [CrossRef]

6. Galatowitsch, S.; Richardson, D.M. Riparian scrub recovery after clearing of invasive alien trees in headwater streams of the Western Cape, South Africa. Biol. Conserv. 2005, 122, 509-521. [CrossRef]

7. Carulla, J.E.; Kreuzer, M.; Machmüller, A.; Hess, H.D. Supplementation of Acacia mearnsii tannins decreases methanogenesis and urinary nitrogen in forage-fed sheep. Aust. J. Agric. Res. 2005, 56, 961. [CrossRef]

8. Grainger, C.; Clarke, T.; Auldist, M.J.; Beauchemin, K.A.; McGinn, S.M.; Waghorn, G.C.; Eckard, R.J. Potential use of Acacia mearnsii condensed tannins to reduce methane emissions and nitrogen excretion from grazing dairy cows. Can. J. Anim. Sci. 2009, 89, 241-251. [CrossRef]

9. Hassanat, F.; Benchaar, C. Assessment of the effect of condensed (acacia and quebracho) and hydrolysable (chestnut and valonea) tannins on rumen fermentation and methane production in vitro. J. Sci. Food Agric. 2013, 93, 332-339. [CrossRef]

10. Gemeda, B.S.; Hassen, A. Effect of tannin and species variation on in vitro digestibility, gas, and methane production of tropical browse plants. Asian-Australas. J. Anim. Sci. 2015, 28, 188-199. [CrossRef]

11. Adejoro, F.A.; Hassen, A.; Akanmu, A.M.; Morgavi, D.P. Replacing urea with nitrate as a non-protein nitrogen source increases lamb growth and reduces methane production, whereas mimosa tannin has no effect. Anim. Feed Sci. Technol. 2019, 259, 114360. [CrossRef]

12. Tondi, G.; Pizzi, A. Tannin-based rigid foams: Characterization and modification. Indust. Crop. Prod. 2009, 9, 356-363. [CrossRef]

13. Arbenz, A.; Avérous, L. Chemical modi fi cation of tannins to elaborate aromatic biobased macromolecular architectures. Green Chem. 2015, 17, 2626-2646. [CrossRef]

14. Adejoro, F.A.; Hassen, A.; Thantsha, M.S. Characterization of starch and gum Arabic-maltodextrin microparticles encapsulating Acacia tannin extract and evaluation of their potential use in ruminant nutrition. Asian-Australas J. Anim. Sci. 2019, 32, 977-987. [CrossRef]

15. Adejoro, F.A.; Hassen, A.; Akanmu, A.M. Effect of lipid-encapsulated acacia tannin extract on feed intake, nutrient digestibility and methane emission in sheep. Animal 2019, 9, 863. [CrossRef] 
16. Missio, A.L.; Tischer, B.; dos Santos, P.S.B.; Codevilla, C.; de Menezes, C.R.; Barin, J.S.; Haselein, C.R.; Labidi, J.; Gatto, D.A.; Petutschnigg, A.; et al. Analytical characterization of purified mimosa (Acacia mearnsii) industrial tannin extract: Single and sequential fractionation. Sep. Purif. Technol. 2017, 186, 218-225. [CrossRef]

17. Van Der Watt, E.; Pretorius, J.C. Purification and identification of active antibacterial components in Carpobrotus edulis L. J. Ethnopharmacol. 2001, 76, 87-91. [CrossRef]

18. Seeram, N.; Lee, R.; Hardy, M.; Heber, D. Rapid large scale purification of ellagitannins from pomegranate husk, a by-product of the commercial juice industry. Sep. Purif. Technol. 2005, 41, 49-55. [CrossRef]

19. Zhou, H.C.; Lin, Y.M.; Wei, S.D.; Tam, N.F.Y. Structural diversity and antioxidant activity of condensed tannins fractionated from mangosteen pericarp. Food Chem. 2011, 129, 1710-1720. [CrossRef]

20. Marino, D.J. Ethyl Acetate. Elsevier Inc. 2005, 1, 144.

21. Cann, A.F.; Liao, J.C. Pentanol isomer synthesis in engineered microorganisms. Appl. Microbiol. Biotechnol. 2010, 85, 893-899. [CrossRef] [PubMed]

22. Pattanaik, B.N.; Mandalia, H.C. Ethyl Acetate: Properties, Production Processes and Applications-A Review. Intern. J. Curr. Res. Rev. 2011, 3, 23-40.

23. van Niekerk, W.A.; Hassen, A.; Snyman, L.D.; Rethman, N.F.G.; Coertze, R.J. Influence of mineral composition and rumen degradability of Atriplex nummularia (Hatfield Select F1) plants on selection preference of sheep. Afr. J. Range Forage Sci. 2009, 26, 91-96. [CrossRef]

24. Adejoro, F.A.; Hassen, A.; Thantsha, M.S. Preparation of acacia tannin loaded lipid microparticles by solid-in-oil-in-water and melt dispersion methods, their characterization and evaluation of their effect on ruminal gas production in vitro. PLoS ONE 2018, 13, e0206241. [CrossRef] [PubMed]

25. Makkar, H.P.S. A laboratory manual for the FAO/IAEA co-ordinated research project on Use of nuclear and related technique to develop simple tannin assays for predicting and improving the safety and efficiency of feeding ruminants on tanniferous tree foliage. In Quantification of Tannins in Tree and Shrub Foliage; IAEA: Vienna, Austria, 2000; 31p.

26. Porter, L.N.; Hrstich, L.J.; Chans, B.G. The conversion of procyanidins and prodelphinidins to cyanidin and delphinidin. Phytochem. 1986, 2, 223-230. [CrossRef]

27. Singh, B.; Sahoo, A.; Sharma, R.; Bhat, T.K. Effect of polethylene glycol on gas production parameters and nitrogen disappearance of some tree forages. Anim. Feed Sci. Technol. 2005, 123, 351-364. [CrossRef]

28. AOAC. Official Method of Analysis; Association of Offcial Analytical Chemists: Washington, DC, USA, 2002.

29. Van Soest, J.B.; Robertson, P.J.; Lewis, B.A. Methods for dietary fiber neutral detergent fiber, and non starch polysaccharides in relation to animal nutrition. J. Dairy Sci. 1991, 74, 3583-3597. [CrossRef]

30. Menke, H.; Steingass, K.H. Estimation of the energetic feed value obtained from chemical analysis and in vitro gas production using rumen fluid. Anim. Res. Dev. 1988, 28, 7-55.

31. Mould, F.L.; Morgan, R.; Kliem, K.E.; Krystallidou, E. A review and simplification of the in vitro incubation medium. Anim. Feed Sci. Technol. 2005, 123-124, 155-172. [CrossRef]

32. Theodorou, M.K.; Williams, B.A.; Dhanoa, M.S.; McAllan, A.B.; France, J. A simple gas production method using a pressure transducer to determine the fermentation kinetics of ruminant feeds. Anim. Feed Sci. Technol. 1994, 48, 185-197. [CrossRef]

33. Pressure to Gas Production Conversion; Ankom Technology: Mecedon, NY, USA, 2014. Available online: https://www.ankom.com/ sites/default/files/document-files/RFS005_Pressure_to_Gas_Production_Conversion.pdf (accessed on 13 July 2018).

34. Tavendale, M.H.; Meagher, L.P.; Pacheco, D.; Walker, N.; Attwood, G.T.; Sivakumaran, S. Methane production from in vitro rumen incubations with Lotus pedunculatus and Medicago sativa, and effects of extractable condensed tannin fractions on methanogenesis. Anim. Feed Sci. Technol. 2005, 123, 403-419. [CrossRef]

35. Tilley, R.A.; Terry, J.M.A. A two-stage technique for the in vitro digestion of forage crops. J. Br. Grassl. Soc. 1963, 18, 104-111. [CrossRef]

36. Engels, F.J.; Van der Merwe, E.A.N. Application of an in vitro technique to South African forages with special reference to the effect to certain factors on the results. South Afr. J. Agric. Sci. 1967, 10, 983-995.

37. Schofield, P. Chapter 10-Gas Production Methods. In Farm Animal Metabolism And Nutrition; D'Mello, J.P.F., Ed.; CABI Publishers: New York, NY, USA, 2000; 433p.

38. Minho, A.P.; Bueno, I.C.D.S.; Gennari, S.M.; Jackson, F.; Abdalla, A.L. In vitro effect of condensed tannin extract from acacia (Acacia mearnsii) on gastrointestinal nematodes of sheep. Rev. Bras. Parasitol. Vet. 2008, 17, 144-148. Available online: http:/ / www.ncbi.nlm.nih.gov/pubmed/20059834 (accessed on 15 January 2018). [PubMed]

39. Bhatta, R.; Saravanan, M.; Baruah, L.; Sampath, K.T.; Prasad, C.S. Effect of plant secondary compounds on in vitro methane, ammonia production and ruminal protozoa population. J. Appl. Microbiol. 2013, 115, 455-465. [CrossRef]

40. Kardel, M.; Taube, F.; Schulz, H. Different approaches to evaluate tannin content and structure of selected plant extracts-review and new aspects. J. Appl. Bot. Food Qual. 2013, 166, 154-166. [CrossRef]

41. Animut, G.; Puchala, R.; Goetsch, A.L.; Patra, A.K.; Sahlu, T.; Varel, V.H.; Wells, J. Methane emission by goats consuming diets with different levels of condensed tannins from lespedeza. Anim. Feed Sci. Technol. 2008, 144, 212-227. [CrossRef]

42. Patra, A.K.; Saxena, J. A new perspective on the use of plant secondary metabolites to inhibit methanogenesis in the rumen. Phytochemistry 2010, 71, 1198-1222. [CrossRef] 
43. Sirohi, S.K.; Goel, N.; Pandey, P. Efficacy of different methanolic plant extracts on anti-methanogenesis, rumen fermentation and gas production kinetics in vitro. Open Vet. J. 2012, 2, 72-77.

44. Jayanegara, A.; Leiber, F.; Kreuzer, M. Meta-analysis of the relationship between dietary tannin level and methane formation in ruminants from in vivo and in vitro experiments. J. Anim. Physiol. Anim. Nutr. 2012, 96, 365-375. [CrossRef]

45. Hristov, A.N.; Oh, J.; Firkins, J.L.; Dijkstra, J.; Kebreab, E.; Waghorn, G.; Makkar, H.P.S.; Adesogan, A.T.; Yang, W.; Lee, C.; et al. Special topics-Mitigation of methane and nitrous oxide emissions from animal operations: I. A review of enteric methane mitigation options. J. Anim. Sci. 2013, 91, 5045-5069. [CrossRef] [PubMed]

46. Tan, H.Y.; Sieo, C.C.; Abdullah, N.; Liang, J.B.; Huang, X.D.; Ho, Y.W. Effects of condensed tannins from Leucaena on methane production, rumen fermentation and populations of methanogens and protozoa in vitro. Anim. Feed Sci. Technol. 2011, 169, 185-193. [CrossRef]

47. Akanmu, A.M.; Hassen, A. The use of certain medicinal plant extracts reduced in vitro methane production while improving in vitro organic matter digestibility. Anim. Prod. Sci. 2017, 58, 900-908. [CrossRef]

48. Akanmu, A.M.; Hassen, A.; Adejoro, F.A. Gas Production, Digestibility and Efficacy of Stored or Fresh Plant Extracts to Reduce Methane Production on different substrates. Animal 2020, 10, 146. [CrossRef] [PubMed]

49. Schofield, P.; Pitt, R.E.; Pell, A.N. Kinetics of fiber digestion from in vitro gas production. J. Anim. Sci. 1994, 72, $2980-2991$. [CrossRef] [PubMed]

50. Beauchemin, K.A.; McGinn, S.M.; Martinez, T.F.; McAllister, T.A. Use of condensed tannin extract from quebracho trees to reduce methane emissions from cattle. J. Anim. Sci. 2007, 85, 1990-1996. [CrossRef]

51. Schofield, J.P.; Pell, A.N. Measurement and kinetic analysis of the neutral detergent-soluble carbohydrate fraction of legumes and grasses. J. Anim. Sci. 1995, 73, 3455-3463. [CrossRef]

52. Mir, Z.; Acharya, S.N.; Mir, P.S.; Taylor, W.G.; Zaman, M.S.; Mears, G.J.; Goonewardene, L.A. Nutrient composition, in vitro gas production and digestibility of fenugreek (Trigonella foenum-graecum ) and alfalfa forages. Can. J. Anim. Sci. 1997, 77, 119-124. [CrossRef] 